\title{
The Appendix to the Congressional Record
}

CINCE 1873, beginning with the first $S$ session of the Forty-third Congress, the proceedings of Congress have been officially reported, printed, and published directly by the government. The Congressional Record appears in daily form, containing an account of the proceedings of the previous day, and a semimonthly index is issued. At the end of each session of Congress a bound set of the Record is published, together with a detailed index. With the appearance of this bound set it has been customary for libraries to discard the daily issues. However, a recent rule of the Joint Committee on Printing has raised a serious problem in this respect.

For many years it has been the practice of members of both Houses of Congress, by obtaining the privilege of "leave to print," to insert in the Congressional Record speeches not made on the floor. So long as members confined their remarks strictly to the business at hand the practice was not too open to criticism, but in recent sessions the privilege has been greatly abused and all sorts of extraneous matter has been inserted in the Appendix to the Record. From the first session of the Seventyfifth Congress on January 5, 1937, until the second session of the Eighty-third Congress in 1954, material appearing in the Appendix was published in separate volumes at the end of each session. The results of this practice are very revealing. For each session during that period the Appendix has approximated one-third the length of the Record proper. For the

Dr. Brown is professor of political science, University of Michigan.
Eighty-third Congress, first session, from January 3, 1953, to August 3, 1953, the Congressional Record account of proceedings totaled 11,202 pages and the Appendix 5,402 pages. In the Eightythird Congress, second session, from January 6, 1954, to December 2, 1954, there were 15,290 pages of proceedings and 6,926 of Appendix, totaling 22,216 pages. The cost of the Record (including the biweekly issues) for the fiscal year 1954 was $\$ 1,558,405.39$. A figure of $\$ 80$ per page is used for estimating the cost of the Record material, but the Public Printer states that since the Appendix is set in smaller type, the cost of extraneous material would be nearer $\$ 82$ per page. Based on these estimates the cost of the Appendix in recent years has been about $\$ 600,000$ annually.

It was suggested to members of the Joint Committee on Printing that all extraneous matter now inserted in the Record be omitted, thus saving a large sum of money and producing a more orderly account of the proceedings of Congress. The power to effectuate this reform rests with Congress. By Act of January 12, 1895, the Joint Committee on Printing, consisting of three members of the Senate and three of the House of Representatives, was given control of the arrangement and style of the Congressional Record. The law provided that the Record should be substantially a verbatim report of the proceedings and ordered the Joint Committee to take all needed action for the reduction of unnecessary bulk. No extraneous matter is supposed to go into the Appendix without unanimous approval and consent of the Congress. In 
the hope of controlling, to some extent, the extension of remarks, the rules provide that extensions of two Record pages or more shall be accompanied by an estimate of cost from the Public Printer before permission to extend will be granted. Furthermore, the Rules and Manual of the House of Representatives stipulate that the Congressional Record "is for the proceedings of the House and Senate only, and matters not connected therewith are rigidly excluded."

On June 22, 1953, the Joint Committee on Printing undertook a partial reform. After stating that it was the sense of the Committee "that the printing of extraneous matter in the permanent form of the Congressional Record constitutes unnecessary bulk and a waste of public money," the Joint Committee resolved that beginning with the Eightythird Congress, second session, "all statements prepared by members on subjects in which they are particularly interested, inserted in the Appendix of the daily Congressional Record, shall be moved to the end of the proceedings of the day permission was granted"; and "all extraneous matter including but not limited to newspaper and magazine articles, editorials, addresses, radio programs, commentators' stories, resolutions from organizations and individuals, letters from constituents, etc., together with Members' remarks preceding same, appearing in the Appendix of the daily Congressional Record, shall be omitted from the permanent form of the Congressional Record."

In accordance with these new rules, the bound set of the Congressional Record of the Eighty-third Congress, second session, was made up. Preliminary to its publication the Public Printer stated that only about 1,100 pages of the daily Appendix, out of 6,926, would be carried into the bound set, at an estimated annual saving of $\$ 100,000$ accruing from exclusion of the remainder. If the reform were carried to its ultimate conclusion and all extraneous matter were excluded from issues of the Record, a much larger sum would be saved. Furthermore, under the current plan of publication, in order to have a complete account of everything that is being printed in the Congressional Record, it is necessary for libraries to retain both the daily issues and the bound sets or to have microfilm copies of them.

These facts were presented to Senator Carl Hayden, chairman of the Joint Committee on Printing. While admitting that the Joint Committee concurred in the intent of the recommendation to exclude all extraneous matter from the daily Record, Senator Hayden stated that "it is believed that the adoption of such a measure would result in Members reading material on the floor of the House and Senate thereby delaying important legislation and cluttering the body of the Record with extraneous matter with no saving effected in the overall cost of the Record." In rebuttal of this argument, it might be pointed out that if the respective Houses enforced their rules, and members of Congress exercised due restraint, no extraneous material would be read at any time, thereby avoiding the possible abuses mentioned by Senator Hayden.

The question was also raised with the Joint Committee as to which edition of the Record - the daily or the final bound one-ought to be microfilmed for permanent use. It was the committee's opinion that microfilm companies should film the daily edition "so that librarians and others who do not have the space to store that edition may obtain the same from the Microfilm people."

This recommendation took no account of the desire of many librarians to possess a copy of all material inserted in the daily Appendix but not printed in the bound permanent set of the 
Record. On March 2, 1955, as a partial check on this excluded material, the Joint Committee on Printing adopted a resolution which directed the Congressional Record Index Office to include in the index for the bound volumes a listing of all material appearing in the daily Record and to show the omitted material by a symbol. This order was put into effect with the index volume for the Eighty-third Congress, second session, references to material in the Appendix being prefaced by the letter $A$.

However, there still remained the problem of preserving the material covered by this index and future similar indexes. To meet this problem, as well as those of space and cataloging, University Microfilms of Ann Arbor, Michigan, has adopted a policy of microfilming the bound set of the Congressional Record in its entirety, including index and Daily Digest, and the daily set, with its bimonthly index. It might be added that this bimonthly index of the daily issue is not cumulative, but any difficulty resulting from this fact can be met by consulting the index to the bound set where, as already noted, the material appearing in the daily issue, but omitted from the bound set, is indicated by the symbol $A$.

A wide choice is now afforded librarians. Some will wish to keep copies of bound and daily sets of the Record; some may retain copies of the bound set only; others because of lack of space may want none. All are now able to satisfy their needs through microfilms.

Large savings in cost of government printing and in microfilming could be effected if members of Congress were obliged to conform to the rules governing insertion of extraneous material in the Congressional Record. Some indica- tion of the abuse of the rules, as respects the sessions of the Eighty-third Congress, have already been cited. Further evidence of the abuse is seen in the reports of the closing days of the first session of the Eighty-fourth Congress. On August 3,1954 , the day the Senate adjourned, the Appendix totaled 229 pages of extended remarks and extraneous matter. After adjournment, but under permission to extend remarks, members read 184 pages of material into the Appendix of August 16 and 219 pages into the issue of August 25.

The second session of the Eightyfourth Congress promises no relief. On January 5, 1956, the report of proceedings totaled 115 pages and the Appendix 104; for January 9 the ratio was 122 pages to 63; for January 12 it was 115 to 129. Even permitting the publication of extensions of remarks which may have some justification because of the large number of members and their resultant inability to be heard at length on the floor of the respective Houses, and the inclusion of significant material which might have a relation to legislation, there still remain many pages of the Appendix for which there is no justification. At $\$ 82$ a page the government's bill-and hence that of the taxpayeris excessive. And this takes no account of the cost to libraries of the additional space needed for storage, or for microfilms if that is the form in which they preserve the Congressional Record.

In these days of steadily mounting governmental expenditures and taxation and demands that the budget be balanced it might be recommended that economy, like charity, ought to begin at home, and that Congress in its control of the Congressional Record should put the rule into effect. 